\title{
Efficacy of Sofosbuvir Plus Ribavirin with and without Pegylated Interferon in Management of Egyptian Chronic Hepatitis C Patients
}

\author{
Magdy Al Dahshan ${ }^{1}$, Samy Zaky², Sameh Mohamed Seif El-Din ${ }^{3}$, \\ Mohammed Salah Ali ${ }^{1}$, Alaa Nouh ${ }^{4}$, Radi Hammad ${ }^{3}$ \\ ${ }^{1}$ Internal Medicine Department, Al-Azhar University, Cairo, Egypt \\ ${ }^{2}$ Tropical Medicine Department, Al-Azhar University, Damita, Egypt \\ ${ }^{3}$ Internal Medicine Department, National Hepatology and Tropical Medicine Research Institute, \\ Cairo, Egypt \\ ${ }^{4}$ Tropical Medicine Department, Menoufia University, Menoufia, Egypt
}

Corresponding Author Radi Hammad

Mobile:

00201224778267

E mail:

dr_radyhammad@hot mail.com

Key words: HCV, DAAs, Sofosbuvir
Background and study aim: Egypt is one of the highest prevalence of antibodies to hepatitis $\mathrm{C}$ virus (HCV) in the world, estimated nationally at $6.3 \%$. Applying best treatment protocol has a great impact on the national disease burden. DAAs open the door to decrease $\mathrm{HCV}$ prevalence as well as to treat infected subjects.

Patients and Methods: In this study 1000 patients treated by Pegylated interferon, Sofosbuvir and weight adjusted Ribavirin. Another group of 1000 patients treated by Sofosbuvir and weight adjusted Ribavirin.

Results: Two groups showed sustained virological response : $90.1 \%$ and $72.3 \%$

\section{INTRODUCTION}

The World Health Organization has declared hepatitis $\mathrm{C}$ a global health problem, with approximately $3 \%$ of the world's population (roughly 170200 million people) infected with HCV. In the US, approximately 3 million people are chronically infected, many of whom are still undiagnosed. In Egypt the situation is quite worse. [1]

In Egypt, hepatitis $\mathrm{C}$ is highly endemic, in 2015, a demographic health survey (DHS) was carried out in Egypt revealing $\mathrm{HCV}$ anti-body prevalence nationwide of $6.7 \%$ and HCV RNA of $4.4 \%$ in age group (1-59). [2]

The goal of antiviral therapy is to cure hepatitis $\mathrm{C}$ via a sustained elimination of the virus. Importantly, long-term benefits of sustained virological response (SVR) are the reduction of respectively. Both groups approved that previous treatment status and viral load has no impact on response prediction. Both showed that males are more likely to respond than females.

Conclusion: Addition of Direct Acting Antivirals (DAAs), like sofosbovir, to the standard treatment with interferon and ribavirin improved the duration of the treatment and the sustained virological response (SVR). Treating of cirrhotics by $\mathrm{PEGINF}+\mathrm{SOF}+\mathrm{RBV}$ and $\mathrm{SOF}+\mathrm{RBV}$ leads to decrease success rates. Validation of SVR once will be a golden rule.

HCV-related hepatocellular carcinoma and overall mortality. [3]

The development of pegylated interferon $\alpha$ (PEG-IFN) improved the pharmacokinetics of IFN, allowing more convenient dosing intervals and resulting in higher SVR. [4] In HCV G4, the most prevalent in Egypt. Sustained virological response in Egyptian patients treated with PEGIFN alfa-2a and ribavirin was estimated to be around 60\%. [5]

The standard treatment of the $\mathrm{HCV}$ was PEG IFN+RBV. The preliminary results indicated that $51 \%$ of patients (most with HCV genotype 4, which causes approximately $90 \%$ of $\mathrm{HCV}$ infections in Egypt) achieved a sustained virological response [6]

The development of direct-acting antiviral agents (DAAs) against $\mathrm{HCV}$ 
has revolutionized the treatment of chronic hepatitis C. In 2011, the first selective protease inhibitors (PI) were approved for patients with HCV Genotype1. Boceprevir (Victrelis ${ }^{\circledR}$ ) and telaprevir (Incivek $\AA$; Incivo®) improve SVR rates by up to $75 \%$ in naïve HCV Genotype 1 patients. [7] \& [8]

On December 6, 2013, FDA approved SOVALDI (sofosbuvir) tablets for the treatment of chronic hepatitis $\mathrm{C}(\mathrm{CHC})$ infection as a component of a combination antiviral treatment regimen in subjects with HCV genotype 1,2,3 or 4 infection, for HCV Genotype 4 infection as a triple therapy with Peg INF +RBV. [9]

Treatment with interferon is associated with troublesome side effects, including influenza-like symptoms, depression, fatigue, and cytopenias, and requires weekly subcutaneous injections. A substantial proportion of patients with $\mathrm{HCV}$ infection are either unable or unwilling to receive an interferon based regimen. [10]

A pilot study evaluated the INF-free combination of SOF+RBV for 12 weeks in HCV-G4 patients of Egyptian ancestry showing 79\% SVR12 in Naïve and 59\%in experienced patients. [11]

This study aims to evaluate the efficacy of Sofosbuvir plus Ribavirin with or without pegylated interferon in management of Egyptian chronic hepatitis $\mathrm{C}$ patients.

\section{PATIENTS AND METHODS}

It is a retrospective cross-sectional study conducted on chronic hepatitis C Egyptian patients with fibrosis score F3 and F4 who attended to National Hepatology and Tropical Medicine Research Institute, Cairo, Egypt to receive antiHCV therapy.

Patients divided into 2 groups :

Group I: (1000) IFN-eligible persons received daily sofosbuvir $(400 \mathrm{mg})$ and daily weightbased RBV (1000 mg [ $<75 \mathrm{~kg}]$ to $1200 \mathrm{mg}$ [ $\geq 75$ $\mathrm{kg}])$ plus weekly PEG INF for 12 weeks.

Group II: (1000) IFN-ineligible/ IFN-unwilling persons received daily sofosbuvir $(400 \mathrm{mg})$ and weight-based RBV (1000 mg [<75 kg] to 1200 $\mathrm{mg}[\geq 75 \mathrm{~kg}])$ for 24 weeks.

\section{RESULTS}

Group I: Age is ranged between 19 and 60 years old (mean $50 \pm 7$ years), Males represent $52.9 \%$ of the group and females represent $47.1 \%$ of the group, $24.9 \%$ of patient was diabetics, Naïve patients represent $72.1 \%$ of the group and experienced patients represent $27.9 \%$ of the group.

End of treatment response was $99.7 \%$ while SVR-wk12 \&24 was the same as shown in table below

Table (1): End of treatment response in group I

\begin{tabular}{|l|c|c|c|c|}
\hline & Frequency & Percent & Valid Percent & Cumulative Percent \\
\hline Negative & 901 & 90.1 & 90.1 & 90.1 \\
\hline Positive & 99 & 9.9 & 9.9 & 100 \\
\hline Total & 1000 & 100.0 & 100 & \\
\hline
\end{tabular}

Actually percentage of negative PCR are exactly the same for weeks 16, 24, 36 (weeks 4, 12, 24 after end of treatment) respectively.

In Group I; Viral load or previous treatment experience didn't has any significant relation with treatment response. But Males were more likely to respond than female significantly. In addition to the age which show significant relationship to response. 
Table (2): Relations to treatment response in group I

\begin{tabular}{|l|c|c|c|l|}
\hline \multicolumn{1}{|c|}{ Factor } & $\begin{array}{c}\text { Odds } \\
\text { ratio }\end{array}$ & $\begin{array}{c}\text { Confidence } \\
\text { interval }\end{array}$ & p-value & \multicolumn{1}{|c|}{ Comment } \\
\hline $\begin{array}{l}\text { Naive Vs. treatment } \\
\text { experienced }\end{array}$ & 1.18 & $0.69-1.99$ & 0.527 & No significant difference \\
\hline Gender & 1.78 & $1.01-2.99$ & 0.026 & $\begin{array}{l}\text { Significant association shows that } \\
\text { males were 1.8 times more likely } \\
\text { to have response to the treatment } \\
\text { therapy than females }\end{array}$ \\
\hline Factor & Df & $\begin{array}{c}\text { Independent t- } \\
\text { test }\end{array}$ & P-value & Comment \\
\hline Age in years & 718 & 3.1 & 0.002 & $\begin{array}{l}\text { There was a significant difference } \\
\text { in between those who } \\
\text { responded to the therapy and those } \\
\text { who did not respond }\end{array}$ \\
\hline $\begin{array}{l}\text { Viral load before } \\
\text { starting the therapy }\end{array}$ & 718 & -0.78 & 0.433 & No significant difference \\
\hline
\end{tabular}

Group 2: Age is ranged between 20 and 60 years old (mean $52 \pm 6$ years), Males represent $61.9 \%$ of the group and females represent $38.1 \%$ of the group, $32.5 \%$ of patient was diabetics, Naiive patients represent $73.5 \%$ of the group and experienced patients represent $26.5 \%$ of the group.
End of treatment response was $99.9 \%$ while SVR-wk12 \&24 was the same as shown in table below

Table (3): End of treatment response in group II

\begin{tabular}{|l|c|c|c|c|}
\hline & Frequency & Percent & Valid Percent & Cumulative Percent \\
\hline Negative & 723 & 72.3 & 72.3 & 72.3 \\
\hline Positive & 277 & 27.7 & 27.7 & 100 \\
\hline Total & 1000 & 100.0 & 100 & \\
\hline
\end{tabular}

Actually percentage of negative PCR are exactly the same for weeks 28, 36, 48 (weeks 4, 12, 24 after end of treatment) respectively.
In Group 2; Viral load, age or previous treatment experience didn't has any significant relation with treatment response. But Males were more likely to respond than female significantly.

Table(4): Relations to treatment response in group II

\begin{tabular}{|l|c|c|c|l|}
\hline \multicolumn{1}{|c|}{ Factor } & $\begin{array}{c}\text { Odds } \\
\text { ratio }\end{array}$ & $\begin{array}{c}\text { Confidence } \\
\text { interval }\end{array}$ & p-value & \multicolumn{1}{|c|}{ Comment } \\
\hline $\begin{array}{l}\text { Naive Vs. treatment } \\
\text { experienced }\end{array}$ & 1.53 & $1.01-2.32$ & 0.05 & No significant difference \\
\hline Gender & 3.37 & $2.16-5.37$ & $<0.001$ & $\begin{array}{l}\text { Significant association shows that } \\
\text { males were 3 times more likely to } \\
\text { have response to the treatment } \\
\text { therapy than females }\end{array}$ \\
\hline Factor & Df & $\begin{array}{c}\text { Independent t- } \\
\text { test }\end{array}$ & P-value & Comment \\
\hline Age in years & 539 & 1.33 & 0.183 & No significant difference \\
\hline $\begin{array}{l}\text { Viral load before } \\
\text { starting the therapy }\end{array}$ & 539 & 0.21 & 0.834 & No significant difference \\
\hline
\end{tabular}




\section{DISCUSSION}

SVR in this study, for patient received triple therapy, is less than Lawitz's trial [13] as it was $96 \%$ but in this study it was only $90.1 \%$, and it could be due to many reasons ; the large number in our study (1000 patients in comparison to 28 patients in Lawitz's trial).In our study we selected the patients with fibrosis stage (F3, F4) only (according to NCCVH protocol) in comparison to Lawitz's trial that didn't assess the degree of fibrosis. Our study included naïve and experienced patients, in comparison to Lawitz's trial included only naïve patients.

SVR in this study, for patient received double therapy, is less than Esmat's trial [12] as it was $90 \%$ but in our study it was only $72.3 \%$ and it could be due to many reasons ; the large number in our study (1000 patients in comparison to 51 patients in Esmat's trial).In our study we selected the patients with fibrosis stage (F3, F4) only (according to $\mathrm{NCCVH}$ protocol) in comparison to Esmat's trial that $23 \%$ of subjects were cirrhotics .Our study included $73.5 \%$ naïve patients and $26.5 \%$ treatment experienced patients, in comparison to Esmat's trial included $14 \%$ naïve patients and $63 \%$ treatment experienced.

Conclusion: Addition of Direct Acting Antivirals (DAAs), like sofosbovir, to the treatment with interferon and ribavirin improved the duration of the treatment and the sustained virological response (SVR). Treating of cirrhotic by $\mathrm{PEGINF}+\mathrm{SOF}+\mathrm{RBV}$ or $\mathrm{SOF}+\mathrm{RBV}$ leads to increase success rates. Validation of SVR once will be a golden rule.

Funding: None.

Conflicts of interest: None.

Ethical approval:Approved

\section{REFERENCES}

1. Mohamed M.K. Epidemiology of HCV in Egypt. The Afro-Arab Liver, Journal 2005; 3:2: 41-52.

2. DHS, 2015: https://dhsprogram.com/pubs/pdf/ FR313/FR313.
3. Van der Meer AJ, Veldt BJ, Feld JJ , Wedemeyer H,Dufour JF, Lammertet $F$ et al. Association between sustained virological response and all-cause mortality among patients with chronic hepatitis $\mathrm{C}$ and advanced hepatic fibrosis. JAMA; 2012, 308:2584-2593.

4. McHutchison JG, Lawitz EJ, Shiffman ML, Muir AJ, Galler GW, McCone J et al.: Peginterferon Alfa-2b or Alfa-2a with Ribavirin for Treatment of Hepatitis C Infection. N Engl J Med; 2009, 361:580-593.

5. El Makhzangy H, Esmat G, Said M, Elraziky M, Shouman S, Refai $\mathrm{R}$ et al. Response to pegylated interferon alfa- $2 \mathrm{a}$ and ribavirin in chronic hepatitis C genotype 4. J Med Virol 2009; 81(9):1576-1583.

6. MMWR Report, (2012): http://www.cdc.gov/ $\mathrm{mmwr} /$ preview/mmwrhtml/mm6129a2.htm .

7. Jacobson IM, McHutchison JG, Dusheiko G, Di Bisceglie AM, Reddy KR, Bzowej NH et al. Telaprevir for previously untreated chronic hepatitis C virus infection. $N$ Engl J Med 2011; 364:2405-16.

8. Poordad F, Dieterich D. Treating hepatitis C: current standard of care and emerging directacting antiviral agents. J. Viral Hepat 2012; 19:449.

9. FDA,(2013): http://www.fda.gov/forconsumers/ byaudience/forpatientadvocates/ucm377920.htm.

10. Edward J. Gane, Catherine A. Stedman, Ding X, Svarovskaia E, Symonds WT et al. Nucleotide Polymerase Inhibitor Sofo-sbuvirplus Ribavirin for Hepatitis C. N Engl J Med 2013;368:34-44

11. Degasperi E, Aghemo A. Sofosbuvir for the treatment of chronic Hepatitis C: between current evidence and future perspectives. Hepatic Medicine: Evidence and Research 2014:6 :25-33.

12. Esmat GE, Shiha G, Omar RF et al. Sofosbuvir plus ribavirin in the treatment of Egyptian patients with chronic genotype $4 \mathrm{HCV}$ infection. [Abstract 959.] 65 $5^{\text {th }}$ Annual Meeting of the American Association for the Study of Liver Diseases (AASLD) 2014; November 7-11, 2014; Boston, MA.

13. Lawitz E, Mangia A, Wyles D, Rodriguez-Torres M, Hassanein T, Gordon SC et al. Sofosbuvir for previously untreated chronic hepatitis C infection., Engl J Med 2013; 368:1878-1887 